\title{
Land consolidation as the driving force behind ecological and economic development of rural areas
}

\author{
Małgorzata Dudzińska, Katarzyna Kocur-Bera \\ Faculty of Geodesy and Land Management, University of Warmia and Mazury, Oczapowskiego 2, 10-720 Olsztyn, Poland
}

\begin{abstract}
The aim of spatial economy is to protect specific attributes of space and to ensure rational spatial planning by stimulating economic processes. Protective activities are initiated to maintain a balance between natural and anthropogenic elements of the environment. Comprehensive land consolidation, also known as full land consolidation, is a measure that most effectively promotes the development of non-urbanized areas. It involves the exchange of land plots as well as other activities that contribute to rural development, including land zoning for public utility projects, construction and surfacing of rural roads, construction of drainage systems and erosion control systems and environmental protection. Consolidation significantly influences space and often leads to dramatic changes in spatial patterns. The process has both positive and negative implications for the natural environment. In recent years, greater emphasis has been placed on nonproductive, including ecological, functions of rural areas. For this reason, land consolidation measures have to account for the environmental value of transformed areas. The study analyzes environmental protection measures that are initiated in the process of land consolidation. The type of protective activities and the environmental impacts of land consolidation projects are discussed.

Qualitative methods, in particular analytical, logical topology and identification methods, were used in the above research tasks. The deployed methods support a comprehensive approach to the analyzed problem and the formulation of optimal solutions. Other research methods involved comparative analysis as well as analyses of literature, documents and legal regulations relating to the discussed issues .
\end{abstract}

Keywords: land consolidation; sustainable development; environmental protection; agricultural areas.

\begin{tabular}{|lr|}
\hline Nomenclature \\
ha & hectare \\
$\%$ & percent \\
\hline
\end{tabular}

\section{Introduction}

Land fragmentation considerably impairs agricultural practices, reduces technical and economic efficiency of production, contributes to environmental degradation and obstructs or inhibits the use of modern agricultural equipment [1]. From an economic point of view, land fragmentation is the main weakness of the Polish agriculture that has adverse economic and social consequences - it reduces farm incomes and prevents the accumulation of capital for investments that could improve the efficiency of farming practices. Farmers supplying small quantities of diverse products find it difficult to maintain high quality standards, in particular in milk production, and sell their produce [2]. This adverse phenomenon also has environmental implications. Checkerboard land patterns contribute to soil erosion, rising water levels and flooding, land surface degradation, land sliding, degradation of humic substances in soil and deterioration of land improvement systems. The discussed problem leads to land fallowing. Farmers who own a large number of small and fragmented plots that are situated far from the farmstead often cease to cultivate the most remote plots of land. Land consolidation measures can also induce environmental changes by gradually eliminating linear structures and other natural features, including boundary strips of land, tree lines, small water courses and ponds, belts of rush plants and communities of herbaceous plants. The above reduces landscape and species diversity as land consolidation is generally associated with increased use of fertilizers and pesticides and greater mechanization. The above landscape components are critical for the preservation of bird species diversity. Monocultures of popular crops, such as maize and rapeseed, are the habitats of very small populations of birds,

Corresponding author: Małgorzata Dudzińska. E-mail address: gosiadudzi@uwm.edu.pl

http://dx.doi.org/10.3846/enviro.2014.204

(C) 2014 The Authors. Published by VGTU Press. This is an open-access article distributed under the terms of the Creative Commons Attribution License, which permits unrestricted use, distribution, and reproduction in any medium, provided the original author and source are credited. 
most of which are represented by only several species [1]. The discussed issues suggest that land consolidation measures can have a positive effect on selected environmental features, but the final outcomes of the process frequently disturb the natural balance. The objective of this study was to identify environmental factors that are positively and negatively influenced by land consolidation projects.

\section{Materials and methods}

The identification of environmental conditions in consolidated agricultural land was preceded by three logically interconnected research tasks.

The research tasks were performed in several stages:

- Identification of environmental conditions in excessively fragmented farmland. Determination of negative and positive environmental impacts associated with land fragmentation.

- Land consolidation as a process that affects the natural environment. Identification of environmental conditions after the completion of land consolidation schemes.

- Determination of protective environmental measures for land consolidation projects.

Qualitative methods, in particular analytical, logical topology and identification methods, were used in the above research tasks [3]. The deployed methods support a comprehensive approach to the analyzed problem and the formulation of optimal solutions. Other research methods involved comparative analysis as well as analyses of literature, documents and legal regulations relating to the discussed issues [4].

\section{Environmental conditions in excessively fragmented farmland}

The degradation of agricultural land resulting from anthropogenic and natural factors leads to a qualitative deterioration of various elements of the agroecosystem, including soil, hydrographic conditions, air, landscape and landscape diversity [5]. Environmental degradation resulting from agricultural activities affects:

- soil quality (risk of wind and water erosion, deterioration of the physical properties of soil due to mechanization, lower content of humic substances, risk of acidification and salinity, risk of pesticide and heavy metal contamination);

- air quality (greenhouse gas emissions to ambient air);

- water quality (nitrogen contamination, phosphorus contamination);

- preservation of rural landscape diversity [6].

Siuta [7] identified eight types of soil degradation, most of which are applicable to agricultural land. They are: deforestation of dry and barren sandy soils, acidification and chemical destabilization of soil, mechanical deformation of soil and plant cover, landform and surface deformation by erosion, land sliding, waste dumping, deterioration of phytoecological resources in water bodies, chemical and biological contamination of soil.

Selected types of land degradation are observed in areas characterized by unsupportive land use patterns. Owing to the specific nature of those areas, degradation processes exacerbate the influence of other factors that have both positive and negative impacts on land.

\subsection{Negative environmental impacts associated with land fragmentation}

\subsubsection{Soil degradation caused by water and wind erosion}

Erosion poses a significant threat for arable land in Poland. According to the Institute of Soil Science and Plant Cultivation (IUNG-BIP), approximately $29 \%$ of Poland's territory, including $21 \%$ of agricultural land and $8 \%$ of forests, are threatened by water erosion (strong erosion affects $4 \%$ of land, moderate erosion $-11 \%$ of land, and weak erosion $-14 \%$ of land). The majority of threatened areas are situated in southern and south-eastern Poland.

Water and wind erosion are natural processes that are often triggered by ineffective land management and land cultivation practices Figure 1, Figure 2 [8]. Water erosion includes degradation caused by rising water levels due to heavy rainfall, flooding and snow melting [1].

Many natural factors and agricultural practices determine the duration, intensity, form and extent of erosive soil degradation. In areas characterized by considerable land fragmentation, those factors include a large number of fields whose orientation relative to sloping terrain obstructs agricultural practices, reluctance to apply contour plowing techniques and unsupportive land use structure.

\subsubsection{Degradation of land improvement systems}

Polish land improvement systems are largely outdated and degraded in areas characterized by significant land fragmentation (Fig. 3, Fig. 4). The above contributes to further damage and degradation of the soil environment. Land improvement systems are introduced not only to protect farmland and soil against erosion and devastation, but they are also the least costly method of counteracting the negative consequences of drought, terracing and flooding. The main aims of soil stabilization and erosion control measures are to: 
- limit erosion,

- protect the productive capacity of soil and prevent adverse changes in soil conditions,

- prevent structural deformation of land, in particular the formation of gullies and valleys that intersect farm fields,

- prevent adverse changes in hydrographic conditions and the extension of the hydrological cycle in the local landscape.

\subsubsection{Land sliding}

Land sliding takes places in areas that are susceptible to this form of land degradation due to their specific geological structure, landform and hydrogeological conditions. This adverse process can be triggered and exacerbated by agricultural practices that affect the stability of the slope. It is most often observed in mountains, foothills, along coastlines and sea shores, including on the Baltic Sea, and stream bed sections. They are sporadically noted at the base of very large heaps of mineral waste and earth excavated from strip mines. The technological progress made in landfilling methods and biological reclamation of dumping grounds minimizes the risk of soil erosion and land sliding.

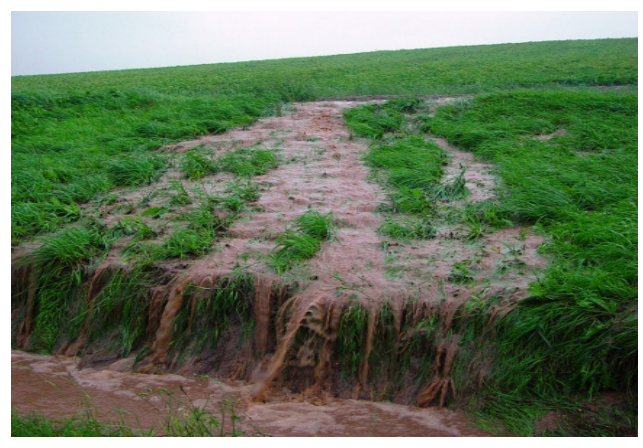

Fig. 1. Soil degradation caused by water erosion

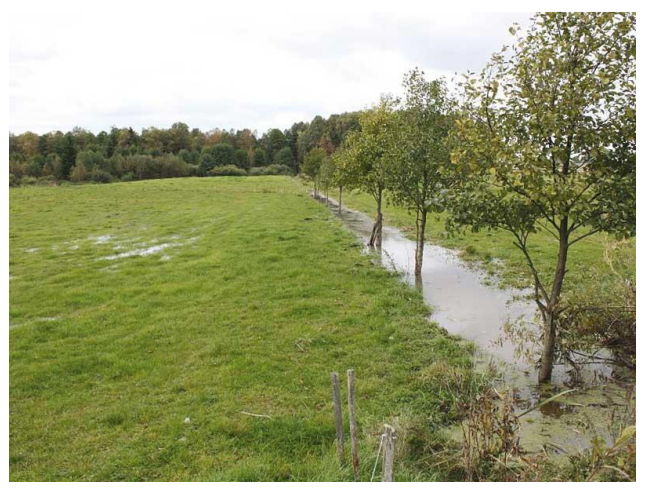

Fig. 3. Degradation of land improvement systems

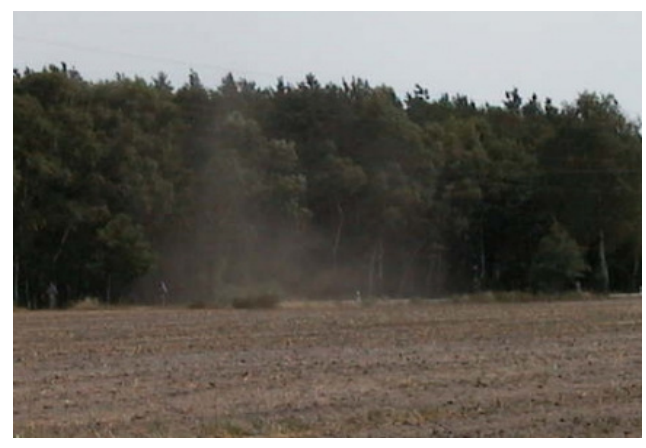

Fig. 2. Soil degradation caused by wind erosion

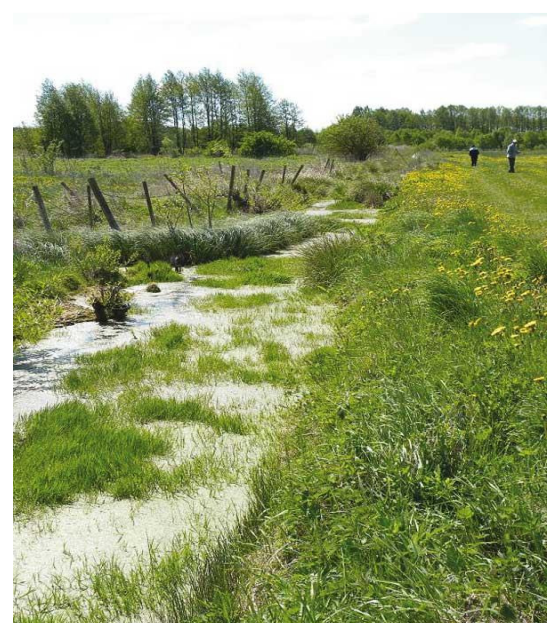

Fig. 4. Degradation of land improvement systems

\subsection{Positive effects}

\subsubsection{The fallowing of arable land, meadows and pastures}

The fallowing of arable land, meadows and pastures:

- limits soil erosion [9],

- improves trophic conditions in soil,

- stimulates soil's biological activity and increases the content of organic compounds in soil,

- improves water and air relations in soil [10],

- minimizes leaching of elements (nitrogen and phosphorus) responsible for the eutrophication of water bodies [11],

- reduces the area of open ecosystems (the succession of shrubs and trees has a negative effect) [12],

- eliminates native species and habitats - negative effect [12].

Since the early 1990s, the effect of fallowing on agroecosystems, including improved soil conditions and greater biological diversity in intensive farming, has been analyzed extensively in numerous research studies published in journals dealing with agricultural and biological sciences [12], [13], [14]. Fallowing programs significantly reduce diffusion pollution from agricultural sources (mainly nitrogen and phosphorus compounds) [11], [15]. In Poland, fallowing schemes 
are introduced mainly due to a drop in agricultural profitability and changes in the structure of agricultural employment [16].

\subsubsection{Reduced problem of excessive fertilization, pesticide and heavy metal contamination}

Excessive fertilizer and pesticide uses leads to:

- changes in habitat conditions,

- eutrophication of water bodies in rural areas,

- poisoning and higher mortality rates of animals at all trophic levels,

- elimination of natural and semi-natural habitats,

- soil degradation resulting from the depletion of flora, expansion of non-native species and lower levels of microhabitat variation that deteriorate the agricultural landscape [12].

Excessive fertilization is less frequently observed in checkerboard farms whose owners cannot afford the relevant treatments. The delayed introduction of advanced agricultural technologies in large farms that conduct intensive operations can also exert both positive and negative effects on the natural environment.

\section{Environmental conditions after the completion of land consolidation projects}

Woch [17] analyzed land consolidation projects in Poland and observed that erosion processes triggered by consolidation had caused considerable damage that, in some cases, outweighed the resulting benefits. The above findings led to a significant reduction in the number of land consolidation projects in areas with natural handicaps. The analyzed consolidation programs did not involve protective measures or land improvement schemes.

\subsection{Negative environmental impacts of land consolidation}

Engineering practices associated with land consolidation have a two-fold impact on biodiversity. Firstly, construction materials can severely disturb or directly damage wildlife habitats. Excessive use of concrete, cement and asphalt not only destroys native biological communities, but it also greatly affects survival capabilities of soil microorganisms. Secondly, engineering practices destroy game trails and migration paths. Artificial construction materials degrade the local landscape, while engineering designs ignore wildlife movement. Land consolidation projects modify the original landscape patterns through land levelling and changing the direction of roads and ditches. Engineering practices can considerably alter the original topography in very short periods of time [18]. Land consolidation measures that have adverse environmental impacts in Poland are presented in Table 1.

Table 1. Land consolidation measures that have adverse and significantly adverse effects on the environment

\begin{tabular}{lll}
\hline Land consolidation measure & Adverse & Significantly adverse \\
\hline Increasing land plot area & $\mathrm{x}$ & $\mathrm{x}$ \\
Changes in the road system & $\mathrm{x}$ & $\mathrm{x}$ \\
Lower afforestation or deforestation & $\mathrm{x}$ & $\mathrm{x}$ \\
Repair of drainage ditches and sewers & $\mathrm{x}$ & $\mathrm{x}$ \\
Zoning large-scale farms & $\mathrm{x}$ & \\
Construction of farm roads & $\mathrm{x}$ & \\
Zoning construction sites & $\mathrm{x}$ & \\
\hline
\end{tabular}

Land consolidation also leads to the intensification of agricultural operations, which is associated with a reduction in the area of mosaic habitats, allocation of more land for farming purposes and conversion of grasslands to arable land. Those processes contribute to a reduction in the area of natural and semi-natural habitats, the elimination of mid-field trees, ponds and strip boundaries, loss of species inhabiting crop fields (both plants, including weeds, and animals), isolation of wildlife enclaves and intensified erosion [2].

A study of two sites in the Western Carpathians [8] revealed that the decrease in the area of strip boundaries resulting from land consolidation projects completed in 1976-1983 ranged from zero (Mogilny) to 0.0209 ha per 1 ha of consolidated land (Jabłonka).

A higher share of winter grains than spring grains in the crop structure has negative implications for bird populations. In early spring, winter cereals are too tall and too dense to enable field birds (skylark, lapwing) to build nests. Birds that typically inhabit farm fields readily nest in spring crops [2].

The increase in cattle populations leads to intensified production of fodder plants in grasslands. Excessive stocking rates contribute to eutrophication due to larger quantities of manure, higher soil erosion, expansion of plant species not consumed by animals and a decrease in the species richness of pastures. Higher stocking rates in pastures generate considerable losses in bird breeding grounds and force many bird species to desert their habitats [2]. 


\subsection{Positive environmental impacts of land consolidation}

Land consolidation and its effect on climate. In Finland to carry out the consolidation has a positive effect on the climate. Consolidation carried out in Järilä resulted in a decrease of working hours at the agricultural production. Thus resulted in a reduction of fuel consumption in production. These actions resulted in a reduction of $\mathrm{CO} 2$ emissions into the atmosphere [19].

\section{Determination of protective measures for land consolidation projects}

Upon joining the European Union, Poland was required to harmonize its spatial planning policies with the EU standards. Poland relied on the professional knowledge, technology and experience of European leaders in the process of developing and implementing land use structure patterns that effectively protect the natural environment, guarantee the required food and raw material production levels and support the maintenance of an ecological balance [20]. Nature conservation areas that support biological diversity and guarantee the stability of the entire ecosystem [21] are established to facilitate environmental management and control.

The land use structure also has a considerable influence on bioecological resources. The dimensions and shape of land plots, land slope and the manner of land use are critical factors that can intensify or minimize soil and landscape degradation. Smaller land plots are less suitable for intensive agricultural practices, which could reduce the risk of adverse environmental impacts [22]. Active erosion control is also required. Erosion control treatments can be permanent (multiannual) or periodic (seasonal). Permanent measures involve infrastructural modifications, including changes in the layout of agricultural land, fields and roads, restoration of gullied landscapes, technical structures (terracing, reinforcement of roads and permanent watercourses, construction of dams), whereas periodic treatments include erosion control and the construction of ditches to evacuate seasonal surface runoffs.

The following protective measures are implemented during land consolidation projects:

Measures that mitigate the adverse effects of land consolidation, Development of environmental impact assessments.

\subsection{Measures that mitigate the adverse effects of land consolidation-Table 2}

Table 2. Measures that mitigate the adverse environmental impacts of land consolidation

\begin{tabular}{lll}
\hline Measure & Highly beneficial & Beneficial \\
\hline Changes in the road system & $\mathrm{x}$ & $\mathrm{x}$ \\
Afforestation & & $\mathrm{x}$ \\
Creation of wind-protected areas & $\mathrm{x}$ & $\mathrm{x}$ \\
Erosion control & $\mathrm{x}$ & $\mathrm{x}$ \\
Erosion control during afforestation & & $\mathrm{x}$ \\
Repair of drainage ditches and sewers & $\mathrm{x}$ & $\mathrm{x}$ \\
Reclamation of degraded areas & & $\mathrm{x}$ \\
Construction of pavements & & $\mathrm{x}$ \\
Construction of farm roads & & $\mathrm{x}$ \\
Zoning construction sites & & $\mathrm{x}$ \\
Zoning nature conservation areas & & $\mathrm{x}$ \\
Zoning grasslands & $\mathrm{x}$ & $\mathrm{x}$ \\
Zoning ponds and lakes & & $\mathrm{x}$ \\
\hline
\end{tabular}

\subsection{Development of environmental impact assessments}

The practice of developing environmental impact assessments differs around the globe. Strategic Environmental Assessment (SEA), a systematic decision-making process aiming to ensure that environmental sustainability aspects are considered effectively in policy, plan and program making, is far more advanced in Canada, United States, Australia and New Zealand [23].

In Poland, an environmental impact assessment (Fig. 5) has to be drafted for land consolidation schemes that cover more than 300 ha. A map in the 1:5000 scale or larger is developed, and the following areas are marked:

- water and marshy areas and other areas with shallow ground water flow,

- coastal areas,

- mountainous areas and forests,

- protected areas, including protected water intake zones,

- protected inland water basins, 
- special conservation areas that are habitats of valuable plant and animal species, protected habitat areas,

- areas that do not meet environmental quality standards,

- inhabited areas - population density,

- areas with landscapes of historical, cultural or archeological value,

- areas with considerable and varied slope, characterized by substantial erosion [23].

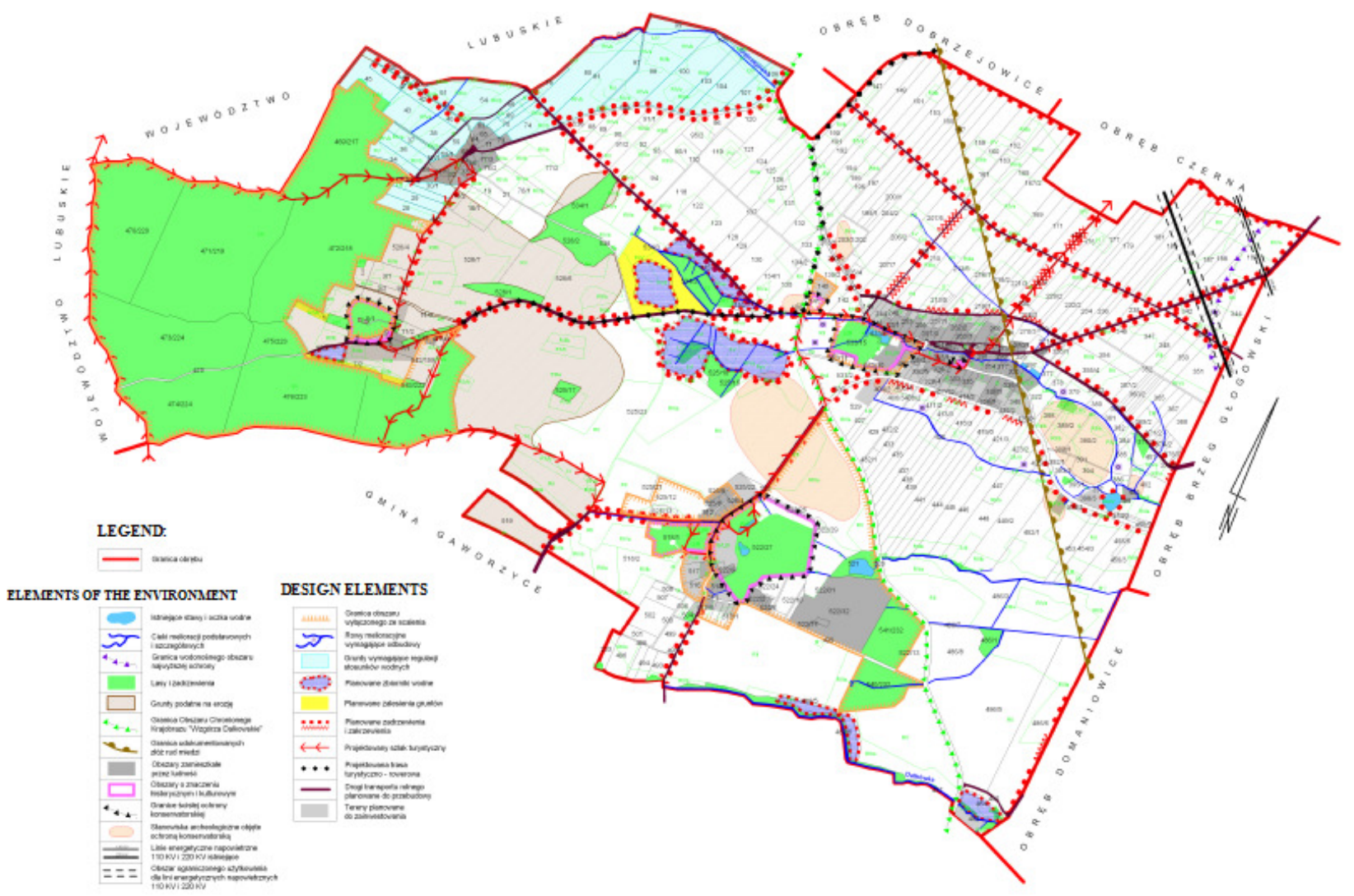

Fig. 5. Strategic Environmental Assessment. Source: Dolnośląskie Biuro Geodezji i Terenów Rolnych

\section{Conclusions}

Sustainable development of agriculture contributes to species and landscape diversity. In line with sustainable development principles, natural capital can be further broken down into renewable and non-renewable resources. For this reason, a strong sustainability approach should be adopted to selected non-renewable resources, whereas a weak sustainability approach should be applied to renewable resources. Every land consolidation project should be accompanied by monitoring efforts to determine the program's influence on the natural environment. If consolidated land is the habitat of endangered and vulnerable species, the restrictive principle of strong sustainability should be adopted, in the light of which natural resources can be exploited only if they are not depleted and can be passed onto the next generations in their original form. In particular, land consolidation causes negative effects when it is applied in areas where land fragmentation is beneficial and it does not constitute a serious problem. 


\section{References}

[1] Siuta, J.; Żukowski, B. 2010. Rozwój i potencjalne zagrożenia agroekosystemów. Część IV. Zagrożenia agroekosystemów, Ochrona Środowiska i Zasobów Naturalnych 43: 80-103.

[2] Dobrzyńska, N. 2003. Ochrona różnorodności biologicznej obszarów wiejskich w Polsce. www.ekoedu.uw.edu.pl/download/wyklady/Dobrzynska.doc

[3] Dawidowicz, A.; Źróbek, R. 2012. Determination of model attributes of a cadastral system in the light of recent scientific advancements. Reports and materials of the Polish Real Estate Scientific Society, Journal of the Polish Real Estate Scientific Society 20(4): 5-18.

[4] Dudzińska, M. 2011. Indicators for evaluating agricultural production areas. Infrastructure and ecology of rural areas (01): 173-185.

[5] Korelewski, K. 2009. Ochrona i kształtowanie terenów rolniczych w systemie kreowania krajobrazu wiejskiego, Infrastructure and Ecology of Rural Areas 4: 5-20.

[6] Domagała-Świątkiewicz, I. 2005. Wptyw działalności rolniczej na środowisko naturalne, ochrona środowiska naturalnego w XXI wieku. Nowe wyzwania i zagrożenia, Kraków.

[7] Siuta, J. (Ed.). 1987. Narodowy program ochrony środowiska i gospodarki wodnej do roku 2010. Problem: Ochrona powierzchni ziemi. Instytut Ochrony Środowiska. Warszawa (maszynopis).

[8] Koreleski, K. 1987. Ochrona gruntów w pracach scaleniowych na przykładzie obiektów z terenu południowej Polski, Geodezja i Urzqdzenia Rolne 6: 27-32.

[9] Van Rompaey, A. J.; Govers. G.; Van Hecke, E.; Jacobs, K. 2001. The impact of land use policy on the soil erosion risk: a case study in central Belgium, Agric. Ecos. Environ 83: 83-94. http://dx.doi.org/10.1016/S0167-8809(00)00173-0

[10] Słowińska-Jurkiewicz, A.; Podstawka-Chmielewska, E.; Pałys, E.; Pranagal, J. 1999. Wpływ odłogowania na wybrane właściwości fizyczne gleby. Fragm. Agron. 62(2): 72-82.

[11] Rekolainen, S.; Gronroos, J.; Barlund, I.; Nikander, A.; Laine. Y. 1999. Modelling the impacts of management practices on agricultural phosphorus losses to surface waters of Finland, Water Sci. Technol. 39: 265-272. http://dx.doi.org/10.1016/S0273-1223(99)00343-1

[12] Kocur-Bera, K. 2012 Identyfikacja zagrożeń występujacych na obszarach wiejskich, Infrastructure and Ecology of Rural Areas. 2: 31-43.

[13] Sotherton, S. W. 1998. Land use changes and the decline of farmland wildlife: an appraisal of the set-aside approach, Biol. Conserv. 83: 259-268. http://dx.doi.org/10.1016/S0006-3207(97)00082-7

[14] Firbank, L. G.; Smart, S.; Crabb, J.; Critchley, C.; Fowbert, J.; Fuller, R.; Gladders, P.; Green, D.; Henderson, I.; Hill, M. 2003. Agronomic and ecological costs and benefits of set-aside in England, Agric. Ecos. Environ. 95: 73-85. http://dx.doi.org/10.1016/S0167-8809(02)00169-X

[15] Kersebaum, K. C.; Steidl, J.; Bauer, O.; Piorr, H. 2003. Modelling scenarios to assess the effects of different agricultural management and land use options to reduce diffuse nitrogen pollution into the river Elbe, Phys. Chem. Earth 28: 537-545. http://dx.doi.org/10.1016/S1474-7065(03)00090-1

[16] Rola, J.; Rola, H. 1998.Ograniczanie zarastania chwastami segetalnymi i ruderalnymi ugorów i odłogów, Bibl. Fragm. Agron. 5: 145-161.

[17] Woch, F. 2005. Ksztaltowanie Środowiska Rolniczego na obszarach urzeźbionych w Polsce, na tle wzorców unijnych, Acta Agrophysica 5(2): 471480 .

[18] Zhang, Q.; Luo, H; Yan, J. 2012. Integrating biodiversity conservation into land consolidation in hilly areas - A case study in southwest China, Acta Ecologica Sinica (32): 274-278. http://dx.doi.org/10.1016/j.chnaes.2012.06.002

[19] Hiironen, J.; Niukkanen, K. 2012. Knowing to manage the territory, protect the environment, evaluate the cultural heritage, in Land consolidation and its effect on climate. FIG Working Week 2012. Rome, Italy, 6-10 May 2012, 1-15.

[20] Harasimowicz, S.; Kostrubiec, A. 2005. Rejestracja obszarów o charakterze naturalnym na potrzeby scaleń, in Nowe tendencje w teorii i praktyce urzadzania terenów wiejskich. Wydawnictwo Uniwersytetu Warmińsko-Mazurskiego w Olsztynie: $123-132$.

[21] Dacko, A. 2006. Tworzenie warunków do rozwoju terenów wiejskich poprzez scalanie gruntów - aspekt teoretyczny, Infrastructure and Ecology of Rural Areas (2): 29-39.

[22] Lee, N. 1997. Evaluacion ambiental estratégica Aplicada politicas, samoloty, y programas M. Peinado, I. Sobrino (red.), Avances pl evaluación de Impacto Ambiental r ecoauditorla, Trotta, Madryt

[23] Przegon, W. 2007. Ochrona środowiska w projektach scaleniowych gruntów. Czasopismo Techniczne (7): 269-275. 